\title{
Effects of Biopolymers from Cassava Implanted with Rodent Bait on Wistar Rats
}

\author{
Oladapo Titus Okareh ${ }^{1}$, Kelechi A. JC-UkA ${ }^{1}$, Ademola Adetokunbo Oyagbemi ${ }^{2}$, \\ Oluwafemi Omoniyi Oguntibeju ${ }^{3 *}$
}

${ }^{1}$ Department of Environmental Health Sciences, Faculty of Public Health, College of Medicine, University of Ibadan, Ibadan, Oyo State, Nigeria

${ }^{2}$ Department of Veterinary Physiology and Biochemistry, Faculty of Veterinary Medicine, University of Ibadan, Nigeria ${ }^{3}$ Phytomedicine and Phytochemsitry Group, Department of Biomedical Sciences, Faculty of Health and Wellness Sciences, Cape Peninsula University of Technology, Bellville 7535, South Africa

Received: 12 April 2021

Accepted: 23 June 2021

\begin{abstract}
The increase in the use of plastic-based materials has resulted in the generation of large volumes of plastic wastes that are non-biodegradable, and this is of public health concern. Hence, there is a need to adopt an eco-friendly technology that is capable of producing plastics that are biodegradable, and less hazardous to man and the environment. The study focuses on the conversion of biopolymer to bioplastic rodent bait and its toxicological effects. The toxicological effect of the product was tested on forty-five male Wistar rats randomly distributed into 9 groups after acclimatization period of two weeks. The groups include: Group 1 (Bioplastic alone); Group 2 (Bait meal $+1.5 \mathrm{~g}$ zinc phosphide); Group 3 (Bait meal $+3 \mathrm{~g}$ zinc phosphide), and Group 4 (Bait meal $+6 \mathrm{~g}$ zinc phosphide). Rats were fed ad libitum for 5 days in which their body weights, morphological changes, and time of death were recorded daily. After exposure experimental to diets, histopathological, biochemical, and haematological parameters were determined. Morphological observations such as reduced activities, fur loss in toxicant fed rats in comparison to the control were observed. The results showed that serum Aspartate Transaminase (AST) and Alanine Transferase (ALT) activities were highest in test groups compared to the control. The histopathological analysis revealed high levels of inflammatory cells, necrosis and haemorrhage within the test groups when compared with the control. Bioplastics produced from cassava residues as rodent bait were highly effective. These bioplastics can be used for the control of household rodents. Therefore, this technology can be adopted for domestic eradication of rodents.
\end{abstract}

Keywords: Cassava residues, bioplastics, rodent bait, plasticizer

*e-mail: oguntibejuo@cput.ac.za 


\section{Introduction}

Cassava is a major staple food in the developing world, providing basic diets for over half a billion people [1-2]. It is one of the most drought-tolerant crops capable of growing on marginal soils. Although, cassava thrives in fertile soil, its comparative advantage over other profitable crops is its ability to grow in acidic soils of low fertility, with sporadic rainfall or long periods of drought [3-4]. Cassava is the third-largest source of carbohydrates in the tropics, after rice and maize [5-6]. It is widely cultivated in tropical Africa, Asia and Latin America, and it is the fourth most important global crop in developing countries, with an estimated production in 2006 of 226 million tones. It is characterized by great diversity of uses as both roots and leaves can be eaten by humans and animals.

Bioplastics otherwise known as biodegradable plastics can be defined as plastics that can be easily broken down by bacteria or other living organisms. They are made from renewable resources (such as corn, tapioca, potatoes, sugar and algae) which break down faster than traditional petroleum-based plastics. Petroleum-based plastics rely more on fossil fuels and in turn produce more greenhouse gases which poses a threat to the environment [7-8]. However, bioplastics can break down in either anaerobic or aerobic environments, depending on how they are manufactured. There are a variety of materials that bioplastics are composed of, and these include: starches, cellulose or other biopolymers [9-10]. Since the use of plastics has become such a universal way of life, it is almost impossible to get rid of it. Hence, biodegradable plastics may serve as a promising solution to the over-loaded landfills, making plastic by a renewable source [11-12]. As a result of the adverse effects of plastic wastes regarding their impacts in the environment, there is the need to adopt an eco-friendly technology that is capable of producing plastics that are biodegradable, less hazardous to man and the environment.

Vectors can be seen as any agent that has the ability to carry or transmit an infectious pathogen (s) into another living organism (s) as described elsewhere [13]. There are various types of vectors ranging from arthropods to mammals. Of the mammals, rodents are the most common examples as it relates to its availability in various environments, as well as households in particular, thus, carrying various diseases. This study provides an alternative to the already known rodent bait by producing one from cassava residues. This will reduce the level of resistance, as well as health hazards that can occur with other forms of rodent baits.

\section{Material and Methods}

\section{Study Design}

A laboratory-based experimental study design was adopted for this study. Cassava processing residues were collected, using composite sampling collection method from various points at the processing center. The starches from the cassava processing residues mostly generated were extracted. The starch extract was used in the production of bioplastics.

\section{Materials}

Three cassava processing residues were collected from Egbeda LGA Gari processing center in Ibadan, Nigeria, mostly from freshly cut cassava peels, cassava waste water and discarded or broken cassava. The selected cassava residues were collected from a single Gari processing center within Ibadan and starch was extracted. Twenty-seven Wistar albino rats were purchased from the Institute of Advanced Medical Research and Technology (IAMRAT), College of Medicine, University College Hospital, Oyo State. Other analytical grade reagents used during the experiment include Sodium Metabisulfite $\left(\mathrm{Na}_{2} \mathrm{~S}_{2} \mathrm{O}_{5}\right)$, Hydrochloric acid $(\mathrm{HCl})$, Sodium Hydroxide $(\mathrm{NaOH})$, Glycerol, Zinc Phosphide ( $\mathrm{ZnP})$, buffered formalin, colouring pigment and Hematoxylin \& Eosin (H\&E) stain.

\section{Methods}

The production of bioplastics ranged from the extraction of starch from broken / discarded cassava, cassava peels and waste water, with the use of reagents to produce preliminary bioplastic which was further turned into bioplastic bait. The following are the methods used in the production of bioplastics and bioplastic rodent bait.

Extraction of starch: The starch was extracted using the wet method as described by Benesi et al. [14] from discarded/broken cassava, cassava peels and cassava waste water.

\section{Preparation of Preliminary Bioplastic Product}

The preliminary bioplastic product was prepared by weighing $100 \mathrm{~g}$ of the extracted cassava starch and dissolved in $100 \mathrm{mls}$ of distilled water. Each of the following- $0.5 \% \mathrm{Na}_{2} \mathrm{~S}_{2} \mathrm{O}_{5}, 0.5 \mathrm{M} \mathrm{HCl}, 0.5 \mathrm{M} \mathrm{NaOH}$ and glycerol were added into the mixture and stirred. Using a double boiler method, the mixture was brought to boil stirring vigorously until a plastic film was observed. A thermometer was inserted into the double boiler to monitor the temperature through the boiling process and allowed to cool at room temperature [15-16].

\section{Collection and Acclimatization of Rats}

Male Wistar strain of albino rats (Rattus norvegicus) with average body weight of 100-140 g were housed in a well ventilated experimental animal house under a 12:12 hour light to darkness cycle. Experimental animals were allowed free access to food and sufficient water ad libitum. 


\section{Drug Treatment/Administration}

The rats were divided into groups and their initial body weights were recorded. Administration of bait was carried out by ingestion for a 5-day period. This was done as follows:

Group 1: Rats with bioplastic alone

Group 2: Rats with bait meal and $1.5 \mathrm{~g}$ of zinc phosphide Group 3: Rats with bait meal and $3.0 \mathrm{~g}$ of zinc phosphide Group 4: Rats with bait meal and $6.0 \mathrm{~g}$ of zinc phosphide

\section{Animal Handling}

All the animals were handled humanely according to the criteria outlined in the 'Guide for the Care and Use of Laboratory Animals' prepared by the National Academy of Science and published by the National Institute of Health. Ethical regulations were followed in accordance with national and institutional guidelines for the protection of animal welfare during experiments [17].

\section{Biochemical and Haematological Study}

Total protein was determined by the method of Lowry et al. [18]. Aspartate aminotransferase (AST) and Alanine aminotransferase (ALT) were determined using Randox test kits [19]. Haematological parameters were determined by using the International Council for Standardisation in Haematology (ICSH) standard procedures.

\section{Histopathological Study}

The animals were anesthetised using chloroform. It was then sacrificed, the liver was harvested, processed and analyzed at the Histopathology Unit, Department of Pathology, University College Hospital, Ibadan, Oyo State, Nigeria. Small pieces of liver tissues were fixed in $10 \%$ formalin, embedded in paraffin wax, and sections of 5-6 $\mathrm{mm}$ in thickness were made, and thereafter stained with Hematoxylin and Eosin for histopathological examination according to the previously described method [20]. Thereafter, the sections were examined with light microscopy.

\section{Statistical Analysis and Data Management}

The results were analyzed using Microsoft Excel 2010 and Statistical Package for Social Sciences (SPSS) version 16. The results were expressed as mean and standard deviation. In comparing the results of the groups, analysis of variance (ANOVA) was applied and the difference was taken to be significant when P-value is $<0.05$ using Duncan tests.

\section{Results and Discussion}

\author{
Nutritional Value of Feed Administered \\ to the Control Group
}

During the trial, various feeds were given to the control group and parameters were assessed to understand the adaptation of these rats to the feeds. A full proximate analysis showed the group fed with the normal rat feed had higher values in its protein content $(22.25 \%)$ as compared to the other feeds. This can be attributed to the constituents that make up the feed which is solely protein and fibre. However, the other formulated feeds- bait meal and bioplastic alone, respectively, showed a higher percentage of carbohydrate $(56.78 \%)$ which can be attributed to the source of feed - starch. Of all the feeds, the bait meal comprising of bioplastic and natural protein source gave a good proportion of all the various components of food. This is in line with the work of Suckow et al. outlining that the required nutrients needed by laboratory animals should include proteins and amino acids, energy, carbohydrates, fats, fibre as well as minerals and vitamins [21].

\section{Morphological Observations of the Control and Test Groups}

In the test groups fed with bait meal with varying concentrations of zinc phosphide (toxicant) and bioplastic, it was observed that they suffered weight loss, loss of appetite, as well as gradual reduction in alertness and aggressiveness. This is as a result of the toxicant used with the bait meal. The mechanism of action as described by the Department of Agriculture, Fisheries and Forestries (DAFF) can be seen when ingested as it releases a tiny quantity of toxic phosphine gas in the acidic conditions of the rat's stomach [22]. This gas causes central nervous system depression, irritation of the lungs and damage of the liver and other organs which furthermore leads to death as a result of heart failure and more commonly pulmonary oedema accompanied by kidney damage. The variations in the time of death of the rats is related to the body weights of the rat - the smaller the weight of the rat, the faster they die while the bigger the weight of the rat, the slower it takes for the rats to die.

In the control group, however, there was a slight reverse as the rats were more active, aggressive as well as an increase in their weight. Amongst the three control groups, the group fed with the bait meal progressively increased adiposity while the control group subjected to the bioplastic alone decreased in weight. This variation is connected to the fact that for every feed to be appealing to rats, the attractant is important. This is in agreement with the findings of Shumake and Hakim who reported that the rat increases its initial rates of 
Table 1. Physico-chemical analysis of Cassava residues.

\begin{tabular}{|c|c|}
\hline Parameters & Values (\%) \\
\hline Moisture & $47.59 \pm 0.30$ \\
\hline Starch & $56.78 \pm 0.47$ \\
\hline Glucose & $5.76 \pm 0.03$ \\
\hline Amylose & $26.79 \pm 0.15$ \\
\hline Carbon & $11.28 \pm 0.40$ \\
\hline Total phosphorus & $0.002 \pm 0.00$ \\
\hline Nitrogen & $0.03 \pm 0.01$ \\
\hline
\end{tabular}

ingestion of the feed in the presence of an attractant [23]. Furthermore, it was observed that the taste as well as texture of the feed played a role in the rat's response to eating. From the research, it was observed that the rats under the bait meal category ate more than that of the conventional rat feed because it was moist as against the regular pellet texture. This finding is in agreement with various works that has been done by Labouré et al. [24] and Oka et al. [25] indicating that taste and texture played a role in feeding patterns and body weight. The physico-chemical properties of the starch from cassava processing residues are reported in Table 4.T he moisture content value was $47.59 \%$, starch was $56.78 \%$, carbon was $11.28 \%$, amylose was $26.79 \%$, glucose was $5.76 \%$, total phosphorus was $0.021 \%$ and nitrogen was $0.03 \%$ (Table 1). The proximate analyses of the feed types administered to the control group are presented in Tables 4. The moisture content for the administered control feed C-1, C-2 and C-3 were $6.50 \%$, $47.60 \%$ and $42.50 \%$ respectively, crude fibre were $4 \%$, $2 \%$ and $3 \%$ respectively, crude protein were $22.25 \%$, $11.38 \%$ and $2.28 \%$, respectively, and ether extract were $8.1 \%, 5.9 \%$ and $2.1 \%$, respectively, (Tables 2, 3 and 4). Weight reduction was observed for treatment of group 2 and 4 which was not significant while group 3 was significant when compared with the control for days 1 and 21 (Fig. 1). Table 5 shows changes in weight of the rats in the experimental groups. No abnormality was observed in the feed intake but in the water intake, the arsenic group consumed more water than all the groups. The control feed intake was the lowest while the arsenic group consumed more feeds and water intake.

The results of Total protein, Albumin, Globulin, Albumin/Globulin ratio indices of this study are presented in Table 6. The treatment groups were not statistically significant $(\mathrm{p}>0.05)$ when compared with the control, though the values of the control group for total protein, albumin, globulin were the highest in this study. Aspartate aminotransferase in group 2 as shown in Table 6 increased in group 4 compared with the control. Also ALT in group 4 and 1 were very similar but not significant statistically $(\mathrm{p}>0.05)$. The arsenic group (30 \pm 3.2 ) had the highest values of ALT, compared with group 1, group 3 (29.7 \pm 0.58 ) and group 4 (Table 6).
Table 2. Proximate Analysis of Normal Rat feed.

\begin{tabular}{|c|c|}
\hline PARAMETERS & VALUES (\%) \\
\hline Moisture & $6.50 \pm 0.03$ \\
\hline Crude fibre & $4.00 \pm 0.02$ \\
\hline Crude protein & $22.25 \pm 0.10$ \\
\hline Crude fat & $8.10 \pm 0.01$ \\
\hline Dry matter & $93.50 \pm 0.48$ \\
\hline Ash & $6.00 \pm 0.07$ \\
\hline
\end{tabular}

Table 3. Proximate Analysis of Formulated Rat feed (Bioplasticbait meal).

\begin{tabular}{|c|c|}
\hline Parameters & Values (\%) \\
\hline Moisture & $47.60 \pm 0.50$ \\
\hline Crude fibre & $2.00 \pm 0.01$ \\
\hline Crude protein & $11.38 \pm 0.70$ \\
\hline Crude fat & $5.90 \pm 0.01$ \\
\hline Dry matter & $52.40 \pm 0.37$ \\
\hline Ash & $1.50 \pm 0.00$ \\
\hline
\end{tabular}

Table 4. Proximate Analysis of Formulated Rat Feed (Bioplastic alone).

\begin{tabular}{|c|c|}
\hline Parameters & Values (\%) \\
\hline Moisture & $42.50 \pm 0.46$ \\
\hline Crude fibre & $3.00 \pm 0.02$ \\
\hline Crude protein & $2.28 \pm 0.01$ \\
\hline Crude fat & $2.10 \pm 0.01$ \\
\hline Dry matter & $57.50 \pm 0.36$ \\
\hline Ash & $0.01 \pm 0.00$ \\
\hline
\end{tabular}

The result of the haematological indices in this study is presented in Table 7. Most parameters were not statistically significant when compared with the control, though there was an increase or reduction in the values across the treatment groups. White blood cell (WBC) counts $\left(\mu \mathrm{L} / \mathrm{mm}^{2}\right)$ increased in the treatment group in this order 3, 4 and 5 compared with the control. The arsenic fed group had the highest value of the WBC level of this study. Also, Table 7 shows the results of Platelets, lymphocyte, Eosinophil, Neutrophils and $\backslash$ Monocyte. There was a significant increase $(p<0.05)$ in the platelet count of the arsenic group and when compared with the control in this study $(p<0.05)$. Lymphocyte counts of the control and group 3 were very close to each other while the Lymphocyte counts of the arsenic group and the group 4 were lowered in this study (Table 7). The lymphocyte, Eosinophil, 


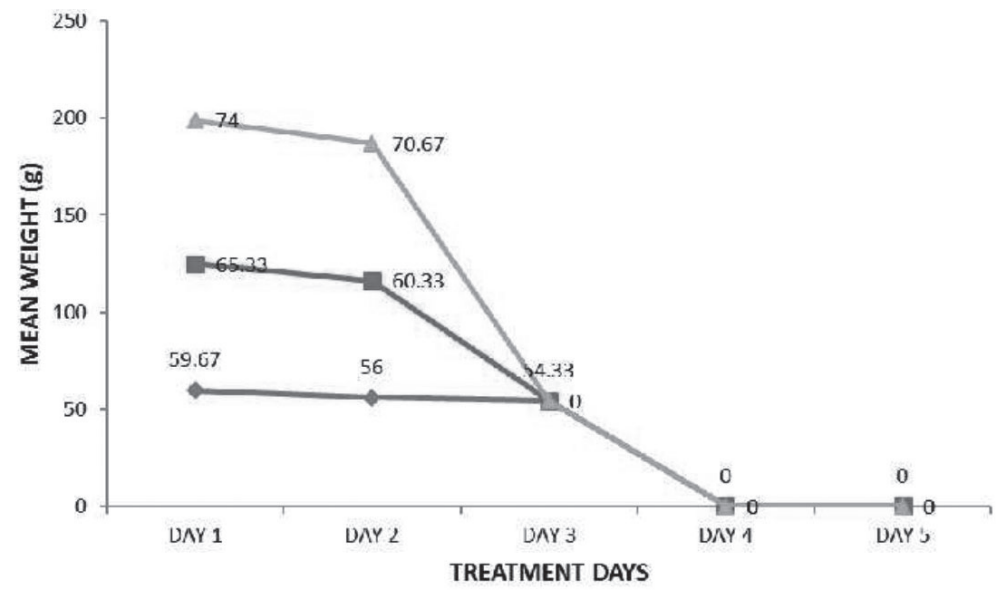

$\rightarrow$ Bait Meal $+1.5 \mathrm{~g}$ toxicant - -Bait Meal $+3.0 \mathrm{~g}$ toxicant - Bait Meal $+6.0 \mathrm{~g}$ toxicant

Fig. 1. Mean weight value of test group fed with bait meal and varying concentrations of active ingredient (zinc phosphide) during the 5-day treatment.

Neutrophil and Monocyte were not statistically significant $(\mathrm{p}<0.05)$ across the groups.

The correlation across these parameters showed that there was a positive significant correlation $(\mathrm{r}=0.359$, $\mathrm{p}=0.066$ ) between packed cell volume (PCV) and white blood cells (WBC) thus, as PCV increased or decreased, WBC went in the same direction. In the same vein, there was a positive non-significant correlation $(\mathrm{r}=0.018, \mathrm{p}=0.928)$ between packed cell volume $(\mathrm{PCV})$ and the platelets $(\mathrm{Pt})$. However, there was a negative correlation $(\mathrm{r}=-0.025, \mathrm{p}=0.903)$ between white blood cells (WBC) and the platelets $(\mathrm{Pt})$ counts. Lymphocytes counts decrease are frequently noted in the initial stages of invasion of foreign materials indicating diseases that affect the immune system. An increase in the number of lymphocytes is usually noted in prolonged illnesses.

Table 5. Feed intake, water intake and change in weight for day 1 and 21.

\begin{tabular}{|c|c|c|c|c|}
\hline Parameter & Group 1 & Group 2 & Group 3 & Group 4 \\
\hline Feed intake & $57.8 \pm 9.4$ & $65.6 \pm 16.3$ & $61.4 \pm 28.1$ & $63.6 \pm 16.2$ \\
\hline Water intake & $169 \pm 58.4$ & $213.1 \pm 47.9$ & $180.1 \pm 29.8$ & $195.5 \pm 35.5$ \\
\hline Change in weight $(\mathrm{g})$ & $28.6 \pm 5.81$ & $28.4 \pm 5.9$ & $10.6 \pm 4.5$ & $23.4 \pm 9.2$ \\
\hline
\end{tabular}

Group 1: Rats with bioplastic alone

Group 2: Rats with bait meal and $1.5 \mathrm{~g}$ of phosphide

Group 3: Rats with bait meal and 3.0g of Zinc phosphide

Group 4: Rats with bait meal and 6.0g of Zinc phosphide

Table 6. Mean biochemical function of rats across treatment groups.

\begin{tabular}{|c|c|c|c|c|c|c|}
\hline Group & Total Protein & Albumin & Globulin & Albumin/globulin ratio & $\begin{array}{c}\text { Asparttate } \\
\text { aminotransferase }\end{array}$ & $\begin{array}{c}\text { Alanine } \\
\text { aminotransferase }\end{array}$ \\
\hline Control & $8.3 \pm 0.52^{\mathrm{b}}$ & $5.0 \pm 0.38^{\mathrm{b}}$ & $3.27 \pm 0.15^{\mathrm{b}}$ & $1.5 \pm 0.10^{\mathrm{a}}$ & $39.0 \pm 6.1^{\mathrm{a}}$ & $28.0 \pm 4.4^{\mathrm{a}}$ \\
\hline Group 2 & $8.0 \pm 0.74^{\mathrm{b}}$ & $4.9 \pm 0.44^{\mathrm{a}}$ & $3.1 \pm 0.31^{\mathrm{b}}$ & $1.5 \pm 0^{\mathrm{a}}$ & $45.0 \pm 6.1^{\mathrm{b}^{*}}$ & $30 \pm 3.2^{\mathrm{b}}$ \\
\hline Group 3 & $8.0 \pm 0.80^{\mathrm{b}}$ & $4.97 \pm 0.42^{\mathrm{a}}$ & $3.0 \pm 0.42^{\mathrm{b}}$ & $1.63 \pm 0.12^{\mathrm{b}}$ & $38.7 \pm 2.52^{\mathrm{a}}$ & $29.7 \pm 0.58^{\mathrm{a}}$ \\
\hline Group 4 & $8.2 \pm 0.26^{\mathrm{b}}$ & $5.0 \pm 0.26^{\mathrm{b}}$ & $3.20 \pm 0.06^{\mathrm{b}}$ & $1.53 \pm 0.05^{\mathrm{a}}$ & $39.7 \pm 3.5^{\mathrm{a}}$ & $28.3 \pm 3.06^{\mathrm{a}}$ \\
\hline
\end{tabular}

All data were mean and standard deviation of 3 replicates. Superscripts of different alphabets indicate significant differences when compared with the control group ta $\mathrm{P}<0.05$. Mean $\pm \mathrm{SD}(\mathrm{n}=5)$.

Group 1: Rats with bioplastic alone

Group 2: Rats with bait meal and 1.5g of phosphide

Group 3: Rats with bait meal and 3.0g of Zinc phosphide

Group 4: Rats with bait meal and $6.0 \mathrm{~g}$ of Zinc phosphide 
Table 7. Mean Haematological indices of rat across treatment groups.

\begin{tabular}{|c|c|c|c|c|}
\hline Group & PCV & Hb & RBC & WBC \\
\hline Control & $49.3 \pm 3.06^{\mathrm{a}}$ & $16.4 \pm 0.8^{\mathrm{b}}$ & $8.4 \pm 0.9^{\mathrm{b}}$ & $3650 \pm 983.6^{\mathrm{a}}$ \\
\hline Group 2 & $46.0 \pm 4.0^{\mathrm{a}}$ & $15.3 \pm 1.4^{\mathrm{a}}$ & $7.8 \pm 0.9^{\mathrm{a}}$ & $5600 \pm 3315.1^{\mathrm{c}^{*}}$ \\
\hline Group 3 & $45.7 \pm 4.04^{\mathrm{a}}$ & $15.2 \pm 1.2^{\mathrm{a}}$ & $7.6 \pm 0.7^{\mathrm{a}}$ & $3650 \pm 4783.3^{\mathrm{a}}$ \\
\hline Group 4 & $49.3 \pm 3.1^{\mathrm{a}}$ & $16.4 \pm 0.93^{\mathrm{b}}$ & $8.7 \pm 0.4^{\mathrm{b}}$ & $5300 \pm 526.8^{\mathrm{a}}$ \\
\hline
\end{tabular}

All data were mean and standard deviation of 3 replicates. Superscripts of different alphabets indicate significant differences when compared with the control group ta $\mathrm{P}<0.05$. Mean $\pm \mathrm{SD}(\mathrm{n}=5)$.

Group 1: Rats with bioplastic alone

Group 2: Rats with bait meal and $1.5 \mathrm{~g}$ of phosphide

Group 3: Rats with bait meal and 3.0g of Zinc phosphide

Group 4: Rats with bait meal and 6.0g of Zinc phosphide

In this study, a decrease in lymphocytes level was noted in the test group - bioplastic with $3.0 \mathrm{~g}$ of zinc phosphide which could result from a more threatening invasion destructing lymphocyte cells in the presence of poor diet intake. In contrast, an increase in lymphocyte levels were observed in the bait meal and varying concentrations of zinc phosphide treatment groups which overall did not show any substantial differences from the controls.

In group three fed with bioplastic alone (Fig. 2), histopathology showed that the central venule and the normal portal tract, scanty infiltrations by inflammatory cells, and the hepatocytes were normal. The toxic effects of zinc phosphide poisoning are thought to result primarily from inhibition of tissue cytochrome oxidase activity. In group four fed with bait meal with $1.5 \mathrm{~g}$ of zinc phosphide, (Fig. 2) showed moderately congested vessels, scanty infiltration of inflammatory cells; the hepatocytes showed varying morphology, while some exhibited hyperchromic nuclei. In group five fed with bait meal with $3.0 \mathrm{~g}$ of zinc phosphide, (Fig. 2) showed few vessels with mild congestion, scanty infiltration of inflammatory cells, while the hepatocytes showed mild infiltration of fat (mild steatosis). Some of the hepatocytes however showed multiple prominent nucleoli and coarsed chromatin while some exhibit vessicular nuclei. In group six fed with bait meal of $6.0 \mathrm{~g}$ of zinc phosphide, there was mild dilatation and few inflammatory cell infiltration (Fig. 2).

The haematological values of the various blood samples from the different groups showed significant differences across the various parameters. This was
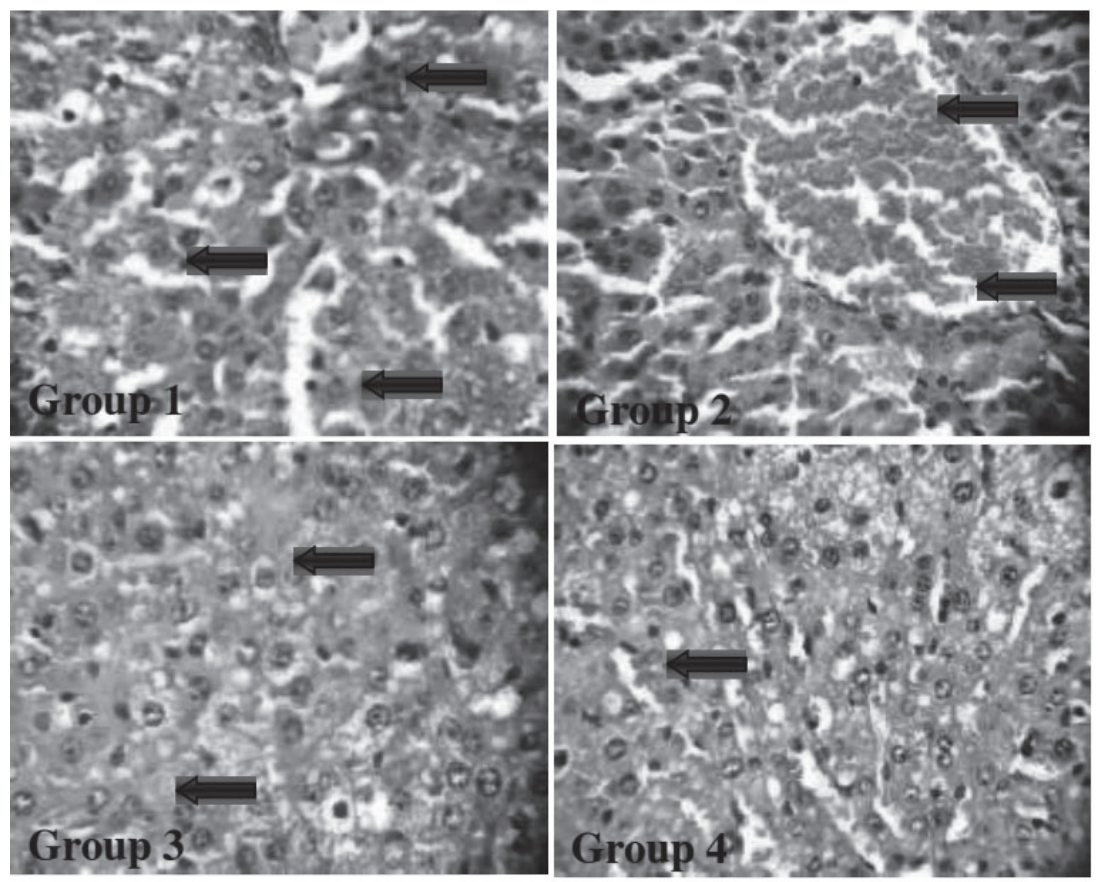

Fig. 2. Histopathology of the liver. Group 1: Rats with bioplastic alone, Group 2: Rats with bałt meal and $1.5 \mathrm{~g}$ of phosphide, Group 3 : Rats with bait meal and $3.0 \mathrm{~g}$ of Zinc phosphide, and Group 4: Rats with bait meal and $6.0 \mathrm{~g}$ of Zinc phosphide. Plates are stained with Hematoxylin-eosin ( $\mathrm{H}$ and $\mathrm{E}$ ) stains and viewed with $\mathrm{x} 400$ objectives. 
Table 8. White blood cell series and differentials of rat across treatment groups.

\begin{tabular}{|c|c|c|c|c|c|}
\hline Group & Platelets $(x 1000)$ & Lymphocyte & Neutrophil & Monocyte & Eosinophil \\
\hline Control & $65.7 \pm 18.2^{\mathrm{a}}$ & $65.0 \pm 7.0^{\mathrm{c}}$ & $32.0 \pm 37.7^{\mathrm{b}}$ & $2.3 \pm 1.5^{\mathrm{b}}$ & $0.3 \pm 0.5^{\mathrm{a}}$ \\
\hline Group 2 & $110.3 \pm 39.1^{\mathrm{c}^{\mathrm{b}}}$ & $59.7 \pm 10.8^{\mathrm{b}}$ & $37.7 \pm 8.5^{\mathrm{b}}$ & $2.0 \pm 1.7^{\mathrm{b}}$ & $0.7 \pm 0.5^{\mathrm{a}}$ \\
\hline Group 3 & $84.3 \pm 41.6^{\mathrm{c}}$ & $68.0 \pm 8.5^{\mathrm{c}}$ & $29.3 \pm 7.0^{\mathrm{a}}$ & $2.3 \pm 1.5^{\mathrm{b}}$ & $0.3 \pm 0.5^{\mathrm{a}}$ \\
\hline Group 4 & $86.3 \pm 25.9^{\mathrm{c}}$ & $48.3 \pm 15.5^{\mathrm{a}}$ & $48.7 \pm 16.8^{\mathrm{c}}$ & $3.0 \pm 2.0^{\mathrm{c}}$ & $1.0 \pm 1.0^{\mathrm{b}}$ \\
\hline
\end{tabular}

All data were mean and standard deviation of 3 replicates. Superscripts of different alphabets indicate significant differences when compared with the control group ta $\mathrm{P}<0.05$. Mean $\pm \mathrm{SD}(\mathrm{n}=5)$.

Group 1: Rats with bioplastic alone

Group 2: Rats with bait meal and $1.5 \mathrm{~g}$ of phosphide

Group 3: Rats with bait meal and 3.0g of Zinc phosphide

Group 4: Rats with bait meal and 6.0g of Zinc phosphide

attributed to the activities within the blood as a result of what was ingested. Across the group, the PCV was lowest in the group subjected to bioplastic and $1.5 \mathrm{~g}$ zinc phosphide (18.33\%) reflecting fewer red blood cell counts in the rat's body. When viewed under the microscope, it was observed that the red blood cells were hypochromic and microcytic as against the other blood samples which were normal. This research recorded significant variation in packed cell volume level, in red blood cell counts as well as haemoglobin concentration of rats fed with the various feeds. However, the decrease in the red blood cell counts was not significant. The liver has an important role in the regeneration of red blood cells [26-28]. According to Eissa and Zidan [29-30], reduction in red blood cell counts could result from the failure of the liver to supply the blood circulation with cells from haemohepatic tissues and the possible destructive effect on red blood cells by anti-nutrientive factors. Since PCV levels reflect the extent and efficiency of oxygen uptake and transfer to tissues [31-32], the low values in the test groups may signify a reduction in the body's metabolic activity [33-35].

The white blood cell value was highest under the normal rat feed category $(73.67 \%)$ which can be attributed to the rat's extreme excitement. However, the

Table 9. Kidney function tests.

\begin{tabular}{|c|c|c|}
\hline Group & Blood Urea Nitrogen & Creatinine \\
\hline Control & $16.33 \pm 1.2^{\mathrm{b}}$ & $0.73 \pm 0.07^{\mathrm{b}}$ \\
\hline Group 2 & $15.67 \pm 1.5^{\mathrm{a}}$ & $0.7 \pm 0.26^{\mathrm{b}}$ \\
\hline Group 3 & $16.0 \pm 1.0^{\mathrm{b}}$ & $0.77 \pm 0.21^{\mathrm{b}}$ \\
\hline Group 4 & $15.0 \pm 1.7^{\mathrm{a}}$ & $0.67 \pm 0.12^{\mathrm{a}}$ \\
\hline
\end{tabular}

All data were mean and standard deviation of 3 replicates. Superscripts of different alphabets indicate significant differences when compared with the control group ta $\mathrm{P}<0.05$. Mean \pm SD $(n=5)$.

Group 1: Rats with bioplastic alone

Group 2: Rats with bait meal and $1.5 \mathrm{~g}$ of phosphide

Group 3: Rats with bait meal and 3.0g of Zinc phosphide

Group 4: Rats with bait meal and 6.0g of Zinc phosphide bait meal and $6.0 \mathrm{~g}$ zinc phosphide category $(70.67 \%)$, the white blood cell counts showed the presence of an inflammation and certain levels of tissue damage. WBCs are involved in the cellular and humoral defense of the organism against foreign material [36-38]. Increase in the level of white blood cell counts is common where there is prolonged exposure to potentially toxic agent or persistence of an injurious agent. However, the effect of the varying concentrations of toxicant on the mean white blood cell counts was significant, indicating a possible effect on the integrity of the white blood cells. The platelet is seen as the smallest type of blood cell. The platelets as well as fibrinogen are responsible for the repair of all damaged blood vessels as well as blood clotting, and in the prevention of bleeding. It plays major role in controlling haemorrhage which can be summarized as primary aggregation, secondary aggregation, blood coagulation, clot retraction, and clot removal [39-42]. Platelets concentrations as well as PCV are determinants of blood viscosity, which correlates positively to blood pressure [43-45]. The results of this study revealed that the platelet value for the bait meal and $1.5 \mathrm{~g}$ toxicant was recorded as $390.67 \times 10^{9} \mathrm{cells} / \mathrm{ml}$, while the bioplastic meal and $3 \mathrm{~g}$ toxicant recorded $470.00 \times 10^{9}$ cells $/ \mathrm{ml}$. The implication of this high increase in the platelets depicts that there are congested vessel, inflammation and haemorrhage which triggered more production of blood platelet to control bleeding.

In this study, the neutrophil level was increased in all treatment groups except in the bait meal with $3.0 \mathrm{~g}$ of zinc phosphide when compared with the control. The gradual increase in neutrophil counts across the intervals in all treated groups reflects a stressful condition on the immune system [46-47]. These changes are significant, implying that all the treatments elicit a negative effect on neutrophil level. Monocytes play crucial roles in innate and adaptive immunity during inflammation [48-50]. The results of the present study revealed a low count of monocyte cells, which could result from immunosuppression and bone marrow failure and/or damage [51-52]. The result of the present study shows that administration of the various rat baits increased the level of eosinophil counts than the normal. Eosinophils 
are often elevated with allergic reactions [53-55]. In contrast, the control group had decreased eosinophil levels as a result these changes had significant effect on the eosinophil cell counts.

The liver is the key organ for metabolism, secretion, and excretion. It is continuously exposed to xenobiotics, environmental pollutants, and chemotherapeutic agents because of its strategic location in the body. Zinc phosphide toxicity is caused by the release of phosphine that inhibits cytochrome c oxidase which affects the mitochondrial morphology thus inhibiting oxidative respiration. In addition, phosphine can interact to form hydroxyl radical associated damage referred to as lipid peroxidation [56]. Furthermore, reported that acute exposures of zinc phosphide can result in an inhibition of cytochrome c oxidase which affects mitochondrial morphology as well as the liver. Additionally, he explained that zinc phosphide produced various physiological changes in the liver [57].

Liver enzymes (AST and ALT) are liberated into the blood whenever liver cells are damaged and enzyme activity is increased in the plasma [5859]. Results of this study present reduction in AST activity in test groups and control groups. However, there was a significant increase in AST activity of rats in the bait meal group and bioplastic with $6 \mathrm{~g}$ of zinc phosphide. The significantly increased AST activity in the test group suggested that there may be an increase in inflammatory processes when rats are consume bioplastic with $6 \mathrm{~g}$ of zinc phosphide. However, the reductions noticed in the other groups were significant. It has been suggested that the development of toxicity is dependent on the rate and duration of exposure to zinc phosphide in tight conjunction with the capacity for zinc phosphide detoxification. The observations from the study agreed with the fact that the system has the recuperative ability to annul a posing threat to its function within its capability which is solely dependent on the degree of toxicity introduced into the body of the rat. The fact that the activity of the liver enzyme reduced indicates that the treatments as well as the control groups did not have necrotic effect on the liver. On the contrary, ALT activities were elevated in the test groups except in the bait meal with of $3 g$ of zinc phosphide which slightly reduced these activities when compared with the control as all these changes are significant. The elevation of ALT activities could imply the signs of impending leakage from the liver into the blood stream in rats administered bait as earlier discussed during the inflammatory process.

\section{Conclusions}

From the results, it can be concluded that the formulated bait meal could be used as a substitute for the conventional rat feed as this product provides the required nutrition needed by rats. It can also be concluded that bioplastic alone is not sufficient in itself to attract rats over a long period of time because it lacks an attractant source to pull the rats. The test groups showed its ability in eradicating the rats. However, bioplastic with $1.5 \mathrm{~g}$ of zinc phosphide eradicated the rats in less than 6 hours showing the lethality potential of the product.

\section{Acknowledgments}

We would want to thank the technical assistance contributed to this work from the Department of Environmental Health Sciences, Faculty of Public Health, College of Medicine, University of Ibadan, Ibadan, Oyo State, Nigeria. The authors also acknowledge financial support from Cape Peninsula University of Technology (PCUT), Bellville 7535, South Africa.

\section{Conflict of Interest}

The authors declare no conflict of interest.

\section{References}

1. SONNEWALD U., FERNIE A.R., GRUISSEM W., SCHLÄPFER P., ANJANAPPA R.B., CHANG S.H., LUDEWIG F., RASCHER U., MULLER O., VAN DOORN A.M., RABBI I.Y., ZIERER W. The Cassava Source-Sink project: opportunities and challenges for crop improvement by metabolic engineering. Plant J. 103, 1655, 2020.

2. CARVAlHO L.J., AGUSTINI M.A., ANDERSON J.V., VIEIRA E.A., DE SOUZA C.R., CHEN S., SCHAAL B.A, SILVA J.P. Natural variation in expression of genes associated with carotenoid biosynthesis and accumulation in cassava (Manihot esculenta Crantz) storage root. BMC Plant Biol. 16, 133, 2016.

3. ALITUBEERA P.H., EYU P., KWESIGA B., ARIO A.R., ZHU B.P. Outbreak of Cyanide Poisoning Caused by Consumption of Cassava Flour - Kasese District, Uganda, September 2017. MMWR. Morb. Mortal Wkly. Rep. 68, 308, 2019.

4. CORGUINHA A.P.B., CARVALHO C.A., DE SOUZA G.A., DE CARVALHO T.S., VIEIRA E.A., FIALHO J.F., GUILHERME L.R.G. Potential of cassava clones enriched with beta-carotene and lycopene for zinc biofortification under different soil Zn conditions. J. Sci. Food Agric. 99, 666, 2019.

5. LEIFELD V., DOS SANTOS T.P.M., ZELINSKI D.W. AND IGARASHI-MAFRA L. Ferrous ions reused as catalysts in Fenton-like reactions for remediation of agrofood industrial wastewater. J. Environ. Manag. 222, 284, 2018.

6. LIU R., SUN W., ZHANG Y., HUANG Z., HU H., ZHAO M. Preparation of starch dough using damaged cassava starch induced by mechanical activation to develop staple foods: Application in crackers. Food Chem. 271, 284, 2019,

7. AMADU A.A., QIU S., GE S., ADDICO G.N.D., AMEKA G.K., YU Z., XIA W., ABBEW A.W., SHAO 
D., CHAMPAGNE P., WANG S. A review of biopolymer (Poly- $\beta$-hydroxybutyrate) synthesis in microbes cultivated on wastewater. Sci. Total Environ. 756, 143729, 2021.

8. SHAHID S., RAZZAQ S., FAROOQ R., NAZLI Z.I. Polyhydroxyalkanoates: Next generation natural biomolecules and a solution for the world's future economy. Int. J. Biol. Macromol. 166, 297, 2021.

9. ROJAS-BRINGAS P.M., DE-LA-TORRE G.E., TORRES F.G. Influence of the source of starch and plasticizers on the environmental burden of starch-Brazil nut fiber biocomposite production: A life cycle assessment approach. Sci. Total Environ. 769, 144869, 2020.

10. KIM H., SHIN M.S., JEON H., KOO J.M., EOM Y., CHOI S., SHIN G., OH D.X., HWANG S.Y., PARK J. Highly reinforced poly (butylene succinate) nanocomposites prepared from chitosan nanowhiskers by in-situ polymerization. Int. J. Biol. Macromol. 173, 128, 2021.

11. HAWKINS S. FONSECA I.B.F.C., LIMA DA SILVA R., QUIRINO R.L. Aquaculture Waste: Potential Synthesis of Polyhydroxyalkanoates. ACS Omega. 6, 2442, 2021.

12. LIU X., CHEN C., SUN J., WANG X. Development of natural fiber-based degradable nonwoven mulch from recyclable mill waste. Waste Manag. 121, 432, 2021.

13. MURAS A., ROMERO M., MAYER C., OTERO A. Biotechnological applications of Bacillus licheniformis. Crit. Rev. Biotechnol. 1, 2021.

14. BENESI I.R.M., LABUSCHAGNE M.T., DIXON A.G.O., MAHUNGU N.M. Stability of native starch quality parameters, starch extraction and root dry matter of cassava genotypes in different environments. J. Sci. Food Agricultur. e84, 1381, 2004.

15. BILGIN E. Going Bananas! Using Banana peels in the production of bioplastic as a replacement for traditional petroleum-based plastic. Google Sci. Fair., 2003.

16. STEVENS E.S. Green Plastics: An introduction to the new science of Biodegradable plastics. Princeton University Press. 3, 2002.

17. GARBER J.C., BARBEE R.W., BIELITZKI J.T., CLAYTON L.A., DONOVAN J.C. The guide for the care and use of laboratory animals, 8th ed. Institute for Laboratory Animal Research. The National Academic Press, Washington DC, USA. 8, 220, 2011.

18. LOWRY O.H.., ROSEBROUGH N.J., FARR A.L., RANDALL R.J. Protein measurement with the folin phenol reagent. J. Biol. Chem. 193, 265, 1951.

19. REITMAN S., FRANKEL S. Determination of Aspartate amino transferase activity in blood serum and tissues. Am.J. Clin. Pathol. 25, 56, 1957.

20. DRURY R.A., WALLINGTON E.A. Editors Carlton's Histopathological Techniques 4th ed London: Oxford University Press. 139, 1976.

21. SUCKOW M.A., WEISBROTH S.H., FRANKLIN C.L. The Laboratory Rat, Elsevier Academic Press, San Diego, CA. $2^{\text {nd }}$ edition. Chapter 9- Rat Nutrition. 219, 2006.

22. DEPARTMENT OF AGRICULTURE, FISHERIES AND FORESTRIES (DAFF). Zinc Phosphide Fact Sheet: Pest Animal Control PA3 $3^{\text {rd }}$ November 2013 www.biosecurity. qld.gov.au. 2013.

23. SHUMAKE S.A., HAKIM A.A. Evaluating Norway rat response to attractant and repellant odours to improve rodenticide baiting effectiveness. Wildlife Damage Management Conference- proceedings. 19, 2000.

24. LABOURE H., SAUX S., NICOLAIDIS S. Effect of food texture change on metabolic parameters: short- and -long term feeding patterns and body weight. American Journal of Physiology- Regulatory, Integr. Comp. Physiol. 280, R780, 2001.

25. OKA K., SAKUARAE A., FUJISE T., YOSHIMATSU H., SAKATA T., NAKATA M. Food texture differences affect energy metabolism in rats. J. Dental Res. 82, 491, 2003.

26. KWON J.H., HAN S., CHO D., SPAHN D.R., KO J.S., KIM D.Y., JUN J.H., GWAK M.S., KIM G.S. Longer storage of red blood cells does not affect mortality in transfused liver transplant recipients. Transfusion. 58, 2529, 2018.

27. LI Y.S., BAO J., XU Y., WANG T.L. [Clinicopathological analysis of 16 cases of pyrrolizidine alkaloids-associated hepatic sinusoidal obstruction syndrome]. Zhonghua Gan Zang Bing Za Zhi. 28, 332, 2020.

28. VAN HAELE M., SNOECK J., ROSKAMS, T. Human Liver Regeneration: An Etiology Dependent Process. Int. J. Mol. Sci. 20, 2332, 2019.

29. KALTER J.A., GUPTA R., GREENBERG M.R., MILLER A.J., ALLEN J. Hyperhemolysis Syndrome in a Patient with Sickle Cell Disease: A Case Report. Clin. Pract. Cases Emerg. Med. 5, 101, 2021.

30. KEDARISETTY C.K., KUMAR R. Spur Cells Causing Severe and Transfusion-Refractory Anemia in Patients With Acute-on-Chronic Liver Failure. Cureus. 12, e10568, 2020.

31. DANE D.M., CAO K., LU H., YILMAZ C., DOLAN J., THALER C.D., RAVIKUMAR P., HAMMOND K.A., HSIA C.C.W. Acclimatization of low altitude-bred deer mice (Peromyscus maniculatus) to high altitude. J Appl. Physiol. 125, 1411, 2018.

32. VAN REMOORTEL H., DE BUCK E., COMPERNOLLE V., DELDICQUE L., VANDEKERCKHOVE P. The effect of a standard whole blood donation on oxygen uptake and exercise capacity: a systematic review and meta-analysis. Transfusion. 57, 451, 2017.

33. RAMIREZ-JIMENEZ M., MORALES-PALOMO F., ORTEGA J.F., MORENO-CABAÑAS A., GUIO DE PRADA V., ALVAREZ-JIMENEZ L., MORARODRIGUEZ R. Effects of Exercise Training during Christmas on Body Weight and Cardiometabolic Health in Overweight Individuals. Int. J. Environ. Res. Public Health. 17, 4732, 2020.

34. RELJIC D., FRENK F., HERRMANN H.J., NEURATH M.F., ZOPF Y. Effects of very low volume high intensity versus moderate intensity interval training in obese metabolic syndrome patients: a randomized controlled study. Sci. Rep. 11, 2836, 2021.

35. THIVEL D., MASURIER J., BAQUET G., TIMMONS B.W., PEREIRA B., BERTHOIN S., DUCLOS M., AUCOUTURIER J. High-intensity interval training in overweight and obese children and adolescents: systematic review and meta-analysis. J. Sports Med. Phys. Fitness. 59, 310, 2019.

36. KIM E.J., KIM J.Y., CHOI H.Y., LEE H., LEE J., KIM M.S., KIM Y.S., HUH K.H., KIM B.S. Systemic Immunomodulatory Effects of Combinatorial Treatment of Thalidomide and Dexamethasone on T Cells and Other Immune Cells. Yonsei Med. J. 62, 137, 2021.

37. ABDELMONEIM M., EL-NAENAEEY E.Y., ABD-ALLAH S.H., GHARIB A.A., ALHUSSEIN M., ABOALELLA D.A., ABDELGHANY E.M., FATHY M.A., HUSSEIN S. Anti-Inflammatory and Immunomodulatory Role of Bone Marrow-Derived MSCs in Mice with Acute Lung Injury. J. Interferon Cytokine Res. 41, 29, 2021. 
38. WAGAR L.E., SALAHUDEEN A., CONSTANTZ C.M., WENDEL B.S., LYONS M.M., MALLAJOSYULA V., JATT L.P., ADAMSKA J.Z., BLUM L.K., GUPTA N., JACKSON K.J.L., YANG F., RÖLTGEN K., ROSKIN K.M., BLAINE K.M., MEISTER K.D., AHMAD I.N., CORTESE M., DORA E.G., TUCKER S.N., SPERLING A.I., JAIN A., DAVIES D.H., FELGNER P.L., HAMMER G.B., KIM P.S., ROBINSON W.H., BOYD S.D., KUO C.J., DAVIS M.M. Modeling human adaptive immune responses with tonsil organoids. Nat. Med. 27, 125, 2021.

39. PERIAYAH M.H., HALIM A.S., SAAD A.Z.M. Mechanism Action of Platelets and Crucial Blood Coagulation Pathways in Hemostasis. Int. J. Hematol. Oncol. Stem Cell Res. 11, 319, 2017.

40. GHOSHAL K., BHATTACHARYYA M. Overview of Platelet Physiology: Its Hemostatic and Nonhemostatic Role in Disease Pathogenesis. Sci. World J. 781857, 2014.

41. BENDER M., PALANKAR R. Platelet Shape Changes during Thrombus Formation: Role of Actin-Based Protrusions. Hamostaseologie. 41, 14, 2021.

42. PIROLA C.J., SALATINO A., SOOKOIAN S. Pleiotropy within gene variants associated with nonalcoholic fatty liver disease and traits of the hematopoietic system. World J. Gastroenterol. 27, 305, 2021.

43. SHIROKOVA L., NOSKOV S., GOROKHOVA V., REINECKE J., SHIROKOVA K. Intra-Articular Injections of a Whole Blood Clot Secretome, Autologous Conditioned Serum, Have Superior Clinical and Biochemical Efficacy Over Platelet-Rich Plasma and Induce RejuvenationAssociated Changes of Joint Metabolism: A Prospective, Controlled Open-Label Clinical Study in Chronic Knee Osteoarthritis. Rejuvenation Res. 23, 401, 2020.

44. RANUCCI M., DI DEDDA U., BARYSHNIKOVA E. Trials and Tribulations of Viscoelastic-Based Determination of Fibrinogen Concentration. Anesth. Analg. 130, 644, 2020.

45. EMMERSON O., BESTER J., LINDEQUE B.G., SWANEPOEL A.C. The Impact of Two Combined Oral Contraceptives Containing Ethinyl Estradiol and Drospirenone on Whole Blood Clot Viscoelasticity and the Biophysical and Biochemical Characteristics of Erythrocytes. Microsc. Microanal. 24, 713, 2018.

46. LOPREIATO V., VAILATI-RIBONI M., PARYS C., FERNANDEZ C., MINUTI A., LOOR J.J. Methyl donor supply to heat stress-challenged polymorphonuclear leukocytes from lactating Holstein cows enhances 1-carbon metabolism, immune response, and cytoprotective gene network abundance. J. Dairy Sci. 103, 10477, 2020.

47. ZACHUT M., KRA G., NEMES-NAVON N., BENAHARON N., MOALLEM U., LAVON Y., JACOBY S. Seasonal heat load is more potent than the degree of body weight loss in dysregulating immune function by reducing white blood cell populations and increasing inflammation in Holstein dairy cows. J. Dairy Sci. 103, 10809, 2020.

48. SEMAN B.G., VANCE J.K., AKERS S.M., ROBINSON C.M. Neonatal low-density granulocytes internalize and kill bacteria but suppress monocyte function using extracellular DNA. J. Cell Sci. 15, 252528, 2021.

49. TAÏLÉ J., PATCHÉ J., VEEREN B., GONTHIER M.P.
Hyperglycemic Condition Causes Pro-Inflammatory and Permeability Alterations Associated with Monocyte Recruitment and Deregulated NFkappaB/PPARgamma Pathways on Cerebral Endothelial Cells: Evidence for Polyphenols Uptake and Protective Effect. Int. J. Mol. Sci. 22, 1385, 2021

50. MENZNER A.K., ROTTMAR T., VOELKL S., BOSCH J.J., MOUGIAKAKOS D., MACKENSEN A., RESHEQ Y.J. Hydrogen-Peroxide Synthesis and LDL-Uptake Controls Immunosuppressive Properties in MonocyteDerived Dendritic Cells. Cancers (Basel). 13, 461, 2021.

51. AYASOUFI K., PFALLER C.K., EVGIN L., KHADKA R.H., TRITZ Z.P., GODDERY E.N., FAIN C.E., YOKANOVICH L.T., HIMES B.T., JIN F., ZHENG J., SCHUELKE M.R., HANSEN M.J., TUNG W., PARNEY I.F., PEASE L.R., VILE R.G., JOHNSON A.J. Brain cancer induces systemic immunosuppression through release of non-steroid soluble mediators. Brain. 143, 3629, 2020.

52. ZORAN T., WEBER M., SPRINGER J., WHITE P.L., BAUER J., SCHOBER A., LÖFFLER C., SEELBINDER B., HÜNNIGER K., KURZAI O., SCHERAG A., SCHÄUBLE S., MORTON C.O., EINSELE H., LINDE J., LÖFFLER J. Treatment with etanercept and low monocyte concentration contribute to the risk of invasive aspergillosis in patients post allogeneic stem cell transplantation. Sci. Rep. 9, 17231, 2019.

53. GANGWAR R.S., PAHIMA H., PUZZOVIO P.G., LEVISCHAFFER F. Update on Eosinophil Interaction with Mast Cells: The Allergic Effector Unit. Methods Mol. Biol. 2241, 221, 2021.

54. BALLART M.J., MONRROY H., IRURETAGOYENA M., PARADA A., TORRES J., ESPINO A. [Diagnosis and management of eosinophilic esophagitis]. Rev. Med. Chil. 148, 831, 2020.

55. KNUPLEZ E., KIENZL M., TRAKAKI A., SCHICHO R., HEINEMANN A., STURM E.M., MARSCHE G. The anti-parasitic drug miltefosine suppresses human eosinophil activation and ameliorates murine allergic inflammation in vivo. Br. J. Pharmacol. 178, 1234, 2021.

56. YOGENDRANATHAN N., HERATH H.M.M.T.B., SIVASUNDARAM T, CONSTANTINE R, KULATUNGA A. A case report of zinc phosphide poisoning: complicated by acute renal failure and tubulo interstitial nephritis. BMC Pharmacol. Toxicol. 18, 37, 2017.

57. KHEDR S.I., MOKHAMER E.H.M., HASSAN A.A.A., EL-FEKI A.S., ELKHODARY G.M., EL-GERBED M.S.A. Psidium guajava Linn leaf ethanolic extract: In vivo giardicidal potential with ultrastructural damage, anti-inflammatory and antioxidant effects. Saudi J. Biol. Sci. 28, 427, 2021.

58. COŞKUN Ö., ÖZTOPUZ Ö., BÜYÜK B. Possible protective activity of $n$-acetyl cysteine against cisplatininduced hepatotoxicity in rats. Mol. Biol. Rep. 48, 637, 2021.

59. GUL H., AWAIS M., SADDICK S., AHMED Y., SHER KHAN F., AHMED E., AFZAL U., NAQVI S.M.ZA., ASGHAR K.M., GULFRAZ M., KAUKAB R.G. Quantification of biochemical compounds in Bauhinia Variegata Linn flower extract and its hepatoprotective effect. Saudi J. Biol. Sci. 28, 247, 2021. 